ORIGINAL ARTICLE

AFRICAN JOURNAL OF CLINICAL AND EXPERIMENTAL MICROBIOLOGY AJCEM/201176/21202

JANUARY2012 ISBN 1595-689X VOL 13(1)

COPYRIGHT 2012

-http://www.ajol.info/journals/ajcem

AFR. J. CLN. EXPER. MICROBIOL 13(1): 28-34 http:/ / dx.doi.org/10.4314/ajcem/v13i1.2

\title{
REFERENCE VALUES OF CD4-LYMPHOCYTE COUNTS IN HIV SERONEGATIVE PREGNANT WOMEN IN BUEA, CAMEROON
}

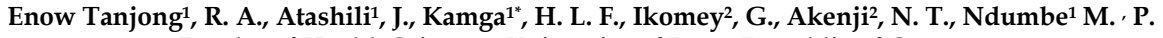 \\ 1. Faculty of Health Sciences, University of Buea, Republic of Cameroon \\ 2. Faculty of Sciences, University of Buea, Cameroon
}

* Correspondence: Henri Lucien Fouamno Kamga (PhD), Faculty of Health Sciences, University of Buea, P.O Box, 63, Buea, Republic of Cameroon, Phone number: (+237) 99721972. E-mail: henrikamga2002@yahoo.f

\begin{abstract}
Pregnancy is a physiologically immunocompromised state, during which alterations in T-lymphocyte subsets may occur. Reference values for CD4 counts in pregnancy have not been established particularly in sub-Saharan populations. This study aimed at describing expected ('normal') values of CD4 counts in healthy HIV-negative pregnant women so these could serve as reference for assessing the progress of HIV disease in HIV-infected pregnant women.

The study was conducted in antenatal clinics in the Buea Health District, Cameroon. All eligible women were interviewed using a standardized questionnaire. Whole blood samples collected were tested for HIV using Determine 1/2 and SD Bioline HIV-1/2 3.0 rapid tests. The CD4+ absolute counts were assessed using the Partec Cyflow Counter and the CD4 easy count kit. A total of 279 women were analysed. Their ages ranged from 15 to 47 years. A vast majority (95\%) of participants were in the second or third trimester of gestation. Slightly less than half $(43 \%)$ were primiparous. The CD4 cell count ranged from 321 to 1808 cells $/ \mu 1$. This distribution was approximately normal with a mean of $851 \mathrm{cells} / \mathrm{\mu l}$, a median of $831 \mathrm{cells} / \mathrm{\mu l}$, and a standard deviation of $254 \mathrm{cells} / \mu \mathrm{l}$. The expected ('normal') range, covering $95 \%$ of the sample was $438-1532$ cells $/ \mu 1$. Participants with malaria parasitaemia tended to have a lower CD4 count (lower on average by 115 cells/ $\mu 1, \mathrm{P}<0.001)$. CD4 cell counts in HIV-negative pregnant women appear similar to those of the general population of HIV-negatives. These values can thus be used as references when assessing HIV-seropositive pregnant women.
\end{abstract}

Keywords: CD4 counts, HIV-negative, pregnancy

Introduction

CD4 counts are widely used as prognostic markers to assess the degree of immune impairment in HIV seropositive individuals and treatment decisions are based on this. They are also used to monitor antiretroviral therapy (ART)[1,2,3,4,5]. Indeed the most recent WHO guidelines on HIV treatment recommend the use of CD4 counts to determine the need for combination antiretroviral therapy in HIVpositive patients, including pregnant women. In 2005, a predictive values of CD4+ lymphocyte count in adult populations in Nigeria published [6]. Before then, reference values of CD4+-cells were not available from West African populations. Rather, values from publications based on studies in Western countries were largely employed for clinical decision making [6]. Evidence in literature suggest significant geographical and racial differences in these parameters; for example, lower CD4+-cell counts have been recorded for Asians compared to Caucasians [7] and studies in African populations have shown mean CD4+cell counts in healthy Ethiopians that are markedly lower than those in Ugandans and Tanzanians [6].

Reference values for CD4 counts in pregnancy are even less known particularly in sub-Saharan populations. Pregnancy is a physiologically immunocompromised state, during which alterations in T-lymphocyte subsets may occur [8,9]. Normal pregnancy has been described as an immune-suppressed state that is induced so that the foetus would not be rejected by the mother's immune system. However, more recent evidence indicates that the immunology of both pregnancy and the sex steroid hormones is exceedingly complex and not fully understood [9]. The foetus is likely protected not by immune suppression in the mother but by changes in Human Leukocyte Antigen (HLA) expression in the trophoblast.

Despite uncertainties on the variation of CD4 counts during pregnancy, CD4 counts are being used to assess the need for treatment in pregnant HIVpositive women in Cameroon and most other resource limited settings. In practice, the CD4 threshold for starting ART in pregnant women is the same as in non-pregnant populations. We hypothesized that this practice may be erroneous if it were confirmed that lower CD4 counts were to be expected in HIV-negative pregnant women. If the latter were true then the CD4 count threshold for initiating antiretroviral therapy in pregnancy may need to be lower than that in non-pregnant populations. There is therefore a need to establish expected ('normal') values of CD4 counts in healthy HIV-negative pregnant women so these could serve as reference for assessing the degree of progress in HIV disease in HIV-infected pregnant women.

\section{Materials and Methods}

This study was conducted in antenatal clinics (ANCs) in the Buea Health District of Cameroon. Two clinics, the Buea Road Health Centre (BRHC) and the Provincial Hospital Annex Buea (PHAB) were used. A previous survey of the ANCs in the 
health district showed that these two ANCs had the highest number of pregnant women for prenatal care. Pregnant women attending these two ANCs were eligible and those who consented were included in the study. All eligible and consenting women were interviewed using a standardized questionnaire. After which about $5 \mathrm{ml}$ of venous blood was collected by venipuncture from each participant into EDTA tubes. These samples were transported from collection sites to the Faculty of Health Science Laboratory, University of Buea, in a cooler containing ice.

Once in the laboratory, the samples were tested immediately for HIV using Determine HIV1/2 (Abbott Co. Ltd. , Japan) and SD Bioline HIV-1/2 3.0 rapid tests (Standard Diagnostics, INC., USA) This was done in conformity with the WHO recommendation Strategy 2 ; which states that HIV can be diagnosed using two rapid tests [10] and this is the diagnostic strategy used in HIV Treatment Centers in Cameroon. The CD4+ absolute counts were done using the Partec Cyflow Counter and the CD4 easy count kit (Partec GmbH, Germany).

The samples were also tested for malaria using a fluorescent microscope (Partec $\mathrm{GmbH}$, Germany). 10ul of whole blood from the EDTA tubes was placed onto the dried-in reagent spot on the test slides. The slides were tilted in all directions in order to distribute the drop of blood. Slides were covered with a cover slip and incubated for 5 minutes. The slides were then placed under the Cyscope. The UV light was switched on and the prescence or not of parasites observed.

\section{Data Analysis}

Data collected were entered into an MS Access interface on Epi-info. Statistical analysis was conducted using STATA version 9 (STATA Corp., College Station, Texas, USA). Participants' demographic characteristics and the variations in the CD4 cell counts in the whole sample were analysed. Variations in mean CD4 cell count (and its variance) by participant characteristics were then compared using Student's t-tests (for characteristics with two categories) and ANOVA tests (for characteristics with more than 2 categories). A priori, the statistical significance level was set at 0.05 while any difference in CD4 count of 100 or more was to be considered meaningful.

\section{Ethical considerations}

Ethical clearance for this study was obtained from the Regional Delegation of Public Health, Buea, Cameroon. Participation in this study was voluntary. A signed consent form was sought from all participants. All procedures were standard and only involved minimal risk to the participants. Study results were returned to patients and incorporated into their care by their respective providers.

\section{Results}

A total of 307 women were approached. Of these, $12(3.9 \%)$ participants did not consent to HIV testing. Sixteen (5.2\%) of the remaining 295 women tested positive for HIV. All HIV-positive cases were excluded from this analysis. The age of participants ranged from 15 to 47 years with a mean (+/standard deviation) of 26 years $(+/-5.56)$. Table 1 summarises the participants' characteristics. A vast majority $(95 \%)$ of participants were either in the second or third trimester of gestation. Slightly less than half $(43 \%)$ were primiparous. Questions on the means of accommodation (used as indicators of socio-economic status) revealed that $15 \%$ were living with relatives.

The CD4 cell counts ranged from 321 to 1808 cells/ $\mu 1$ of blood. The distribution of CD4 counts is shown in Figure 1. This distribution was approximately normal with a mean of 851cells $/ \mu 1$, a median of 831cells/ $\mu \mathrm{l}$, and a standard deviation of 254cells $/ \mu \mathrm{l}$. The $2.5^{\text {th }}$ percentile and $97.5^{\text {th }}$ percentiles were estimated to be 438 cells $/ \mu \mathrm{l}$ and 1532cells/ $\mu$ l respectively, suggesting an expected ('normal') range, covering 95\% of the sample, of 438 to1532 cells $/ \mu l$.

Table 2 shows the variations in the mean CD4 cell counts by participants' characteristics. Overall, there was no substantial (nor statistically significant) variation in CD4 count with characteristics other than malaria. The mean CD4 cell count (SD) in malaria negative pregnant women was 927(275) cells $/ \mu l$ as compared to $818(236)$ cells $/ \mu l$ in malaria positive women.

Figure 2 depicts the CD4 count distribution by malaria status. Malaria positive women still had a significantly lower CD4 cell count than malaria negative women: an average difference of 115 cells $/ \mu \mathrm{l}(\mathrm{P}<0.001)$, even after controlling for other participant characteristics. 
TABLE 1: SUMMARY OF PARTICIPANTS' CHARACTERISTICS

\begin{tabular}{|l|l|}
\hline Characteristics & Number $(\%)^{*}$ \\
\hline Period of gestation & \\
\hline $1^{\text {st }}$ Trimester & $15(5.38)$ \\
\hline $2^{\text {nd }}$ Trimester & $149(53.41)$ \\
\hline $3^{\text {rd }}$ Trimester & $115(41.22)$ \\
\hline Gravidity & \\
\hline 1 & $119(42.65)$ \\
\hline 2 & $52(18.64)$ \\
\hline 3 & $46(16.49)$ \\
\hline 4 & $34(12.19)$ \\
\hline$\geq 5$ & $28(10.05)$ \\
\hline Marital Status & \\
\hline Single & $61(22.18)$ \\
\hline Married & $184(66.91)$ \\
\hline Divorced & $9(3.27)$ \\
\hline Widow & $21(7.64)$ \\
\hline Education & \\
\hline No Education & $9(3.23)$ \\
\hline Primary & $86(30.82)$ \\
\hline Secondary & $123(44.09)$ \\
\hline Tertiary & $61(21.86)$ \\
\hline Means of accommodations & \\
\hline Living with relative & $42(15.11)$ \\
\hline Renting & $187(67.27)$ \\
\hline Living in your own house & $49(17.63)$ \\
\hline & \\
\hline
\end{tabular}

*percentage based on number of respondents

FIGURE 1: CD4 COUNT DISTRIBUTION IN 279 HIV-NEGATIVE PREGNANT WOMEN IN BUEA

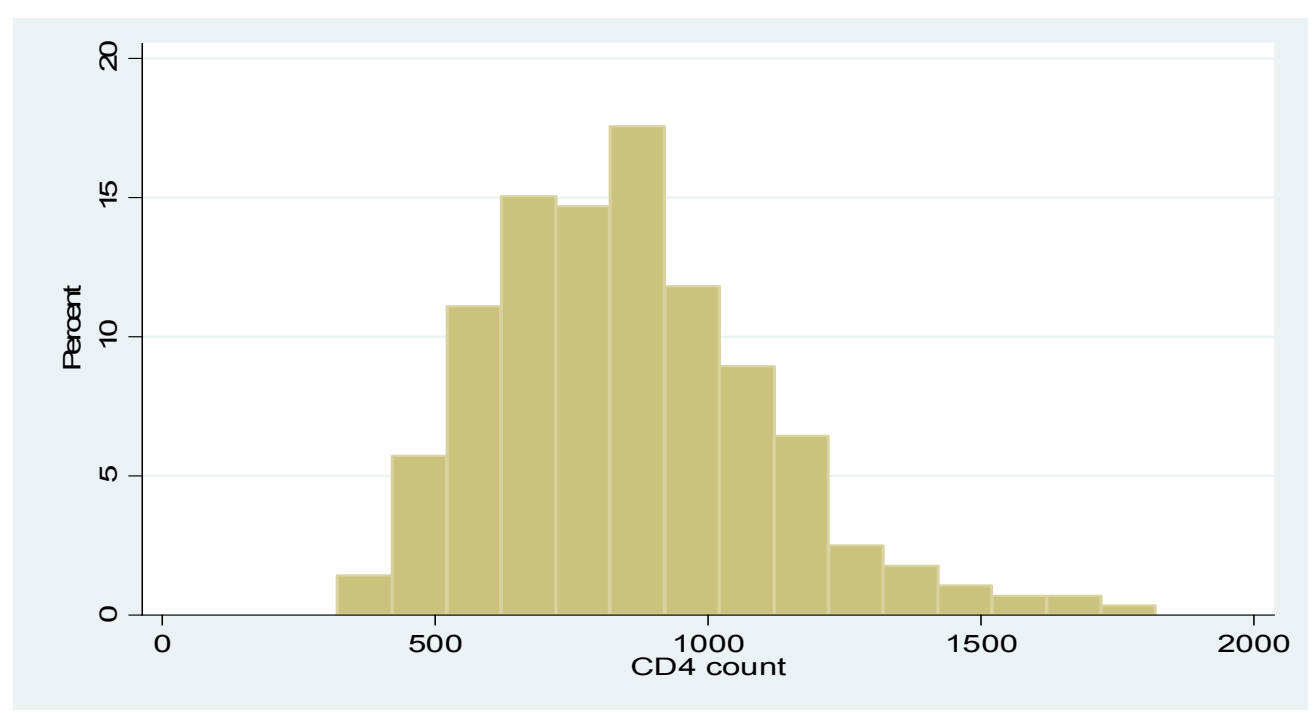

\section{Discussion}

This study aimed at describing reference values of CD4 counts in HIV-negative pregnant women in Buea, South West Region of Cameroon, these CD4 values were found to be normally distributed and similar to values described for non-pregnant HIV negative women in the literature. The study also established that demographic and socio-economic characteristic did not influence CD4 counts in pregnancy.
The mean CD4 values found in this population were within the range of values reported in other HIVnegative populations. The mean CD4 count was higher, by 80 cells/ $\mu l$, than the 771 (250) cells/ $\mu$ l, reported by Aina et al in 2005 in a population of HIV-negative adults in neighbouring Jos, Nigeria [6]. In the Central African Republic, the mean CD4 value in non-pregnant females was 940 cells $/ \mu 1$ [3] a value which was higher, by 89 cells $/ \mu l$, than that observed in our study of pregnant women. In Botswana mean CD4 T-lymphocyte counts (+/- SD) in HIV-seronegative non-pregnant females was 
827(+/- 245), [Bussmann et al, 2004]. Normal values for CD4 and CD8 T lymphocyte subsets in Shanghai was 727/540 cells / ul Jiang et al, 2004. In another study, mean CD4 $\mathrm{T}$ cell values (+/- standard deviation) for adult populations in other nonAfrican population were; Chinese $812(+/-255)$, Malaysian $856(+/-308)$, Indian 958(+/-296) and Hong Kong 812(+/-256) [5].

Similar to our findings, other studies have found little or no relationships between socio-demograhic characteristics and CD4 count levels. A study [6] found no association between gestational ages with CD4 counts. In another investigation carried out on peripheral blood lymphocyte subsets in adolescents, age had no effect on the CD4 + cell counts in the female participants and was found to have no correlation with CD4 lymphocyte count [12].

In this study malaria positive pregnant women tended to have significantly lower CD4 counts. This has also been reported in non-pregnant adult populations [13], and in HIV and malaria positive adults[Chalwe et al, 2009]. In these studies the CD4 count in malaria positive participants was lower by about 300cells $/ \mu \mathrm{l}$ and more than 400cells/ $\mu \mathrm{l}$ respectively. These lower CD4 counts in malaria could be a result of malaria infection impairing the normal functioning of the immune system $[10,15]$. Pregnant women are susceptible to malaria during pregnancy. Plasmodium falciparum sequesters in the placenta. Parasitized cells in the placenta express unique variant surface antigens (VSA) and lack of immunity to these pregnancy-specific variant surface antigens explains some of the pregnancyassociated malaria susceptibility. Peripheral blood $\mathrm{T}$-cell responses may be decreased in malaria and this may be due to trafficking of memory T-cells out of the circulation [16].

\section{FIGURE 2: CD4 COUNT BY MALARIA STATUS}

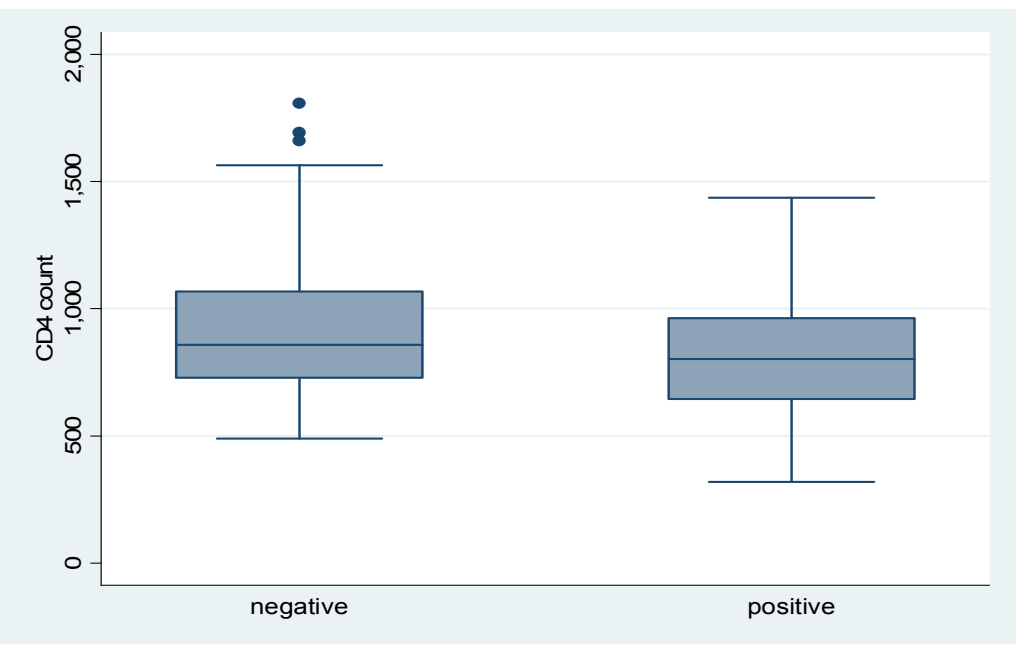


TABLE 2: VARIATIONS IN CD4 LYMPHOCYTE COUNTS N HIV-NEGATIVE PREGNANT WOMEN

\begin{tabular}{|c|c|c|c|c|c|c|c|c|}
\hline $\begin{array}{l}\text { Characteristic } \\
\text { s }\end{array}$ & Level & $\mathbf{N}$ & $\begin{array}{l}\text { Mean } \\
\text { CD4 }\end{array}$ & SD & P-value & $\begin{array}{l}\text { Adjusted } \\
\text { mean } \\
\text { difference } \\
\text { in CD4 }\end{array}$ & $\begin{array}{l}95 \% \\
\text { CI }\end{array}$ & P-value \\
\hline Age & $\begin{array}{l}25 \text { or less } \\
>25 \text { years }\end{array}$ & $\begin{array}{l}139 \\
137\end{array}$ & $\begin{array}{l}846 \\
856\end{array}$ & $\begin{array}{l}275 \\
233\end{array}$ & 0.75 & $\begin{array}{l}21 \\
\text { Ref }\end{array}$ & $-55,97$ & 0.58 \\
\hline Gestation & $\begin{array}{l}1^{\text {st }} \text { Trimester } \\
2^{\text {nd }} \text { Trimester } \\
3^{\text {rd }} \text { Trimester }\end{array}$ & $\begin{array}{l}15 \\
149 \\
115\end{array}$ & $\begin{array}{l}837 \\
842 \\
865\end{array}$ & $\begin{array}{l}324 \\
242 \\
259\end{array}$ & 0.75 & $\begin{array}{l}\text { Ref } \\
37 \\
60\end{array}$ & $\begin{array}{l}- \\
101,17 \\
4 \\
-79,199\end{array}$ & $\begin{array}{l}0.60 \\
0.40\end{array}$ \\
\hline Gravidity & $\begin{array}{l}\text { Primiparous } \\
\text { Not primiparous }\end{array}$ & $\begin{array}{l}119 \\
160\end{array}$ & $\begin{array}{l}841 \\
858\end{array}$ & $\begin{array}{l}267 \\
244\end{array}$ & 0.59 & $\begin{array}{l}\operatorname{Re} \\
27\end{array}$ & $-49,103$ & 0.49 \\
\hline Marital Status & $\begin{array}{l}\text { Married } \\
\text { Not Married }\end{array}$ & $\begin{array}{l}184 \\
91\end{array}$ & $\begin{array}{l}850 \\
862\end{array}$ & $\begin{array}{l}242 \\
277\end{array}$ & 0.71 & $\begin{array}{l}\text { Ref } \\
37\end{array}$ & $-38,112$ & 0.33 \\
\hline Education & $\begin{array}{l}\text { Less than } \\
\text { secondary } \\
\text { Secondary or more }\end{array}$ & $\begin{array}{l}95 \\
184\end{array}$ & $\begin{array}{l}848 \\
853\end{array}$ & $\begin{array}{l}273 \\
244\end{array}$ & 0.88 & $\begin{array}{l}03 \\
\text { Ref }\end{array}$ & $-64,71$ & 0.93 \\
\hline $\begin{array}{l}\text { Accommodati } \\
\text { on }\end{array}$ & $\begin{array}{l}\text { Living } \\
\text { relative } \\
\text { Renting } \\
\begin{array}{l}\text { Living in } \\
\text { house }\end{array}\end{array}$ & $\begin{array}{l}42 \\
187 \\
49\end{array}$ & $\begin{array}{l}840 \\
852 \\
856\end{array}$ & $\begin{array}{l}227 \\
244 \\
314\end{array}$ & 0.95 & $\begin{array}{l}\text { Ref } \\
35 \\
42\end{array}$ & $\begin{array}{l}-63,132 \\
-79,162\end{array}$ & $\begin{array}{l}0.49 \\
0.50\end{array}$ \\
\hline $\begin{array}{l}\text { Phone } \\
\text { ownership }\end{array}$ & $\begin{array}{l}\text { No } \\
\text { Yes }\end{array}$ & $\begin{array}{l}61 \\
218\end{array}$ & $\begin{array}{l}826 \\
858\end{array}$ & $\begin{array}{l}257 \\
253 \\
\end{array}$ & 0.39 & $\begin{array}{l}\text { Ref } \\
36\end{array}$ & $-43,115$ & 0.37 \\
\hline Malaria status & $\begin{array}{l}\text { Negative } \\
\text { Positive }\end{array}$ & $\begin{array}{l}85 \\
194\end{array}$ & $\begin{array}{l}927 \\
818\end{array}$ & $\begin{array}{l}275 \\
236\end{array}$ & $<0.001$ & $\begin{array}{l}115 \\
\text { Ref }\end{array}$ & 48,181 & 0.001 \\
\hline
\end{tabular}

*adjusted for all listed characteristics, obtained using linear regression. Ref=reference level in the comparison of means

If confirmed that pregnant malaria positive women tended to have a lower CD4 count, the malaria status would need to also be taken into account when assessing the need for antiretroviral therapy in an HIV-positive woman. Given the crosssectional nature of the study, we could not establish the long-term evolution of CD4 counts in these malaria positive women. It will be interesting to know whether the low-CD4 counts are only transient and increase after malaria treatment. In which case, in assessing HIV-positive women, a repeat $\mathrm{CD} 4$ assay may be needed in the pregnant women who are also malaria positive, before deciding if they need to be placed on antiretroviral therapy.

This study's findings may however be hampered by some limitations. First, the study was conducted in only one health district and may thus not be representative of the whole country. Secondly, HIV serostatus was determined using rapid tests only -

\section{References}

1. Dayama, A,, Pandit ,D., Mudaliar, S., Bharadwaji, R. (1994). A pilot study on CD4 and CD8 cell counts in Healthy HIV seronegative pregnant women. AIDS 8 (6): 843-7.

2. Anglaret, X., Diagbouga, S., Mortier, E., Meda, N., Verge-Valette, V., SyllaKoko, F., Cousens, S, Laruche, G., Ledru, E., Bonard, D., Dabis, F., Van de Perre, P. (1997). CD4+ T-lymphocyte counts in HIV infection: are European some cases of acute HIV may have been misdiagnosed as being HIV-negative. We suspect that this would have resulted only in a slight underestimation of the mean CD4 counts as the cases of acute HIV would not yet have started depleting their CD4 counts.

\section{Conclusion}

Most studies have reported mean CD4 values of normal adult populations and non pregnant females. Reference values for HIV-negative pregnant women are rare in the literature. In this study we report reference values of mean CD4 Tcell counts of pregnant women in Buea, Cameroon. These values were similar to those of the general population of non-pregnant HIV-negative women. Knowledge of these values will be clinically useful for the monitoring of HIV-seropositive pregnant women.

Standards applicable to African Patients? J Acquir Immune Defic Syndr Hum Retroviro, 14 (4):361-7.

3. Menard, D., Mandeng, M. J., Tothy, M. B., Kelembho, K., Gresenguet, G., Talarmin, A. (2003). Immunohaematological Reference Ranges for Adults from the Central African Republic. Clinical and Diagnostic Laboratory Immunology. 10(3): 443- 
4. Bussmann, H., William, W. C., Masupu, K. V., Peter, T., Gaolekwe, S. M., Kim, S., Reich, A. M., Ahn, S., Wu, Y., Thior, I., Essex, M., and Richard, M. (2004). Low CD4+ T-lymphocyte values in Human Immunodeficiency Virus-Negative Adults in Botswana. Clin Diagn Lab Immunol 11(5): 930-935.

5. Ching, W. J., Tan, G. B., and Kuperan, P. (2004). Establishment of Adult Peripheral Blood Lymphocyte Subset Reference Range for Asian Population by Single-Platform Flow Cytometry: Influence of Age, Sex and Race and Comparison with other Published Studies. Clinical and Diagnostic Laboratory Immunology 11(1): 168-173.

6. Aina, O., Dadik, J., Charurat, M., Amangaman, P., Gurumd, S., Mang, E., Guvit, R., Ndam, L., Datong, P., Daniyam, C., Kanki, P., Abimiku, A. (2005). Reference Values of CD4 T lymphocytes in Human Immunodefficiency Virus-Negative Adult Nigerians. Clinical and Diagnostic Laboratory Immunology 12(4): 525-53.

7. Wotring, L. L., Montgomery, J. P., Mokotoff, E. D., Markowitz, N., Lawrence, R. C. (2005). Pregnancy and Other factors Associated with Higher CD4+ T-cell Counts at HIV Diagnosis in Southeast Michigan 1992-2002. MedGenmed .7(1): 1.

8. Dayama, A., Pandit, D., Mudaliar, S., Bharadwaji, R., Shrotri, A. N. and Joshi, S. (2003). A pilot study on CD4 and CD8 cell count in healthy HIV seronegative pregnantwomen. Indian J.Med. Res 117: 198-200.

9. Anastos, K. (2007). Pregnancy Does Not Accelerate HIV in Women. Good News For women living with HIV. The Journal of Infectious Diseases 196: 971-973.

10. Cheesebrough, M. (2007). District Laboratory Practice in Tropical Countries, part 2, 2nd Edition, Cambridge University Press, London.

11. Jiang, W., Kang, L., Lu, H-Z., Pan, X., Lin, Q., Pan, Q., Xue, Y., Weng, X., and Tang, Y-W. (2004). Normal Values for CD4 Lymphocyte Subsets in Healthy Chinese Adults from Shanghai. Clinical and Diagnostic Laboratory Immunology,11(4) :811-813.

12. Rudy, B. J., Wilson, C. M., Durako, S., Moscick, A-B., Muenze, L., and Douglas, S. D. (2002). Peripheral Blood Lymphocyte Subsets in Adolescents: a Longitudinal Analysis from the REACH Project. Clinical and Diagnostic Laboratory Immunology 9(5): 959-965.

14. Chalwe, V., Vangeertruyden, J-P., Mukwamataba, D., Menten, J., Kamalamba, J., Mulenga, M., D'Alessandro, U. (2009). Increased Risk for Severe malaria in HIV-1 infected Adults, Zambia. Emerging Infectious Diseases 15(5).

15. Kfutwah, A. , Mary, J. Y. , Lemen, B. , Leke, R. , Rousset, D.. (2009). Plasmodium falciparum Infection Significantly Impairs Placental Cytokine Profile in HIV infected Cameroonian Women'. PLos ONE 4(12):e8114.doi:10. 1371/journal.pone.0008114 